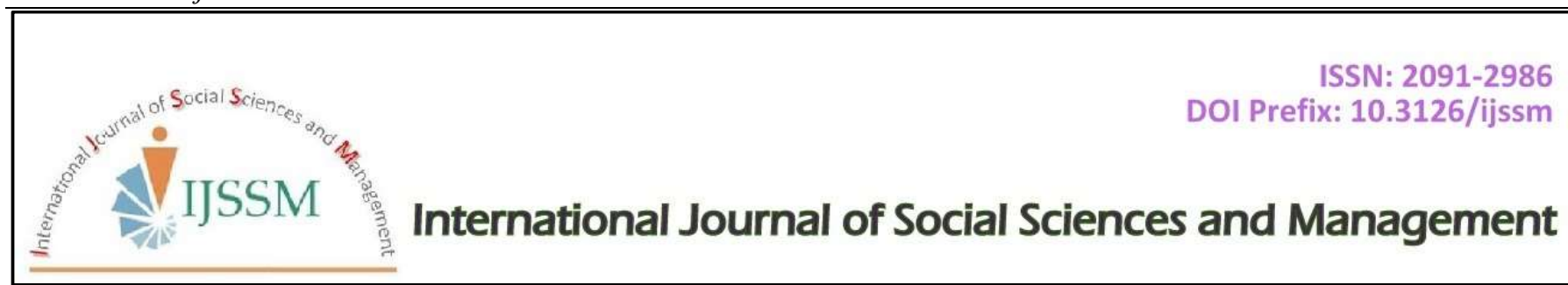

Mini Review

\title{
Unplagiarized Writing- Understanding, Protecting and Staying Original for Students \& Academia
}

\author{
Sanjay Shrivastava \\ Department of Applied Science \& Humanities, NMIMS, MPSTME Shirpur, Maharashtra, India
}

Email: drsanjay.research@gmail.com

\begin{abstract}
As we have advanced in technology, plagiarism has also emerged as an enormous problem. It is constantly threatening the purity and piousness of academics either for faculty researchers or for students. It is troubling academic world by its uncontrolled amplification in academics. The massive use of electronic gadgets has certainly triggered the cause. The easy accessibility has simplified copying for students than ever before making plagiarizing easy. This paper attempts to explore the issue of plagiarism from various dimensions especially students and academics.
\end{abstract}

Keywords: Plagiarism; academic; education; electronic; problem; factors.

\section{Understanding Plagiarism}

"Technology has made plagiarism easier, but it has also made it easier to detect". Wong (2004) pleads that to fight with the problem of plagiarism as brought forth by internet threat various universities across the world have started taking firm measures as they are adopting to "data-sifting tools that can cross check billions of digital documents and swiftly recognize patterns in just seconds". The problem of plagiarism is not new rather it's as old as human civilization. The effect of plagiarism is contagious. With digital-tech development across the world and the wide use of internet the ratio of plagiarism has grown multifold. The high speed search engines are facilitating to provide multiple sources to students to copy and paste the material on any subject and area with far speedier approach. Paldy (1996) sounds bit frustrated saying that plagiarism's effect is like epidemic and 'the problem that won't go away'. "Plagiarism is considered a gross violation of The University's academic and disciplinary standards. Alschuler and Blimling (1995) observed that wide spread of plagiarism also compels to evoke plagiarism as an act of 'epidemic cheating'. The present paper studies the flaring up causes and consequences of student plagiarism and also highlights various issues involved in it. The paper also deals with the significant role of faculty members or academicians in either maximizing the consequences or having an attitude and approach to mitigate this problem.
Hanks (1979), describes plagiarism as 'the act of plagiarizing', which means 'to appropriate (ideas, passages, etc) from (another work or author)'. Plagiarism comprise of literary theft, stealing others' words or ideas and passing them off as one's own without mentioning or acknowledging the original source.

Barnhart (1988) suggested plagiarism as 'literary theft', from the earlier English word plagiary meaning wrongfully taking another's words or ideas. The word plagiarism is in generic sense used to refer to the theft of words, sentences, or ideas, beyond what would normally be regarded as general approach to an issue in terms of common words or most probable sentences. Fialkoff, (1993) stated that plagiarism is 'the misuse of the writings of another author.

Following are the specific conditions where plagiarism occurs:

1. Copying from a web site.

2. Creating a new piece of work on the same theme as an existing one.

3. Citing citations in your work.

4. Quoting from an existing piece of work without reference.

5. Copying short sentences from another source acknowledgement.

6. Copying the words from another source with an acknowledgement. 
7. Using a published work to identify important secondary.

(Source: Marshall and Garry, 2005)

\section{Students and Plagiarism}

The world of academia has been a universal receptor of thoughts, ideas, opinions, suggestions, recommendations and formulated concepts from innumerable sources of great minds including best philosophers, scientists, observes, experts, analysts, teachers, mentors, and business practitioners of vast and varied areas. The core business of the knowledge industry is compiling, collating and imparting such valuable information and ideas. As a loop in the process, there is inevitably great scope for plagiarism within the multi-channeled process. Wojtas (1999) finds that in a common course plagiarism occurs in a variety of settings, including collaboration or cooperation between students working together. Ashworth et al. (1997) found that plagiarism is unattributed use of other people's writings by undergraduates. Baty (2002) observed that master's level students are found more indulged in the act of plagiarism. Morgan \& Thomson (1997), Smith (1995), Macilwain, (1998), and Stone (1996) noticed that doctoral level students are generally found more severely involved in plagiarism where the incidences of PhD students copying of graduate students' work by supervisors or other members of academic staff and taking credit in research grant applications for work done by someone else is more common practice. What is found, Wikipedia is the most potential source for studentmatched content on the Web. The top eight matched sites are shown in Table 1.

Table 1: List of most common websites used in coping practices by students.

\begin{tabular}{|l|l|}
\hline S.N. & websites \\
\hline 1 & www.wikipedia.org \\
\hline 2 & www.answers.yahoo.com \\
\hline 3 & www.answers.com \\
\hline 4 & www.slideshare.net \\
\hline 5 & www.oppapers.com \\
\hline 6 & www.scribd.com \\
\hline 7 & www.coursehero.com \\
\hline 8 & www.medlibrary.org \\
\hline
\end{tabular}

\section{Students' Attitude}

A number of researches have been carried out to study and map out students' perception towards plagiarism and amazingly the studies represented a vast contradiction in students' attitude towards plagiarism and their overall perception and psychology involved in practicing the same. A lot of surveys have unfolded at times which cover the multitude perceptions of students' attitudes and which generally remains contradictory. Roig (2001) brought a study which directly speaks of habit of plagiarism among academic staff and students and found that any such practice in staff members is generally taken more seriously among themselves while on the other corner students nurture this habit and it is found that such practices flourishes when the step in colleges from schools (Sims, 1995). In a study, Sutton \& Huba (1995) found out that the psyche of students generally forms a kind of behavior which encompasses cheating and all associated activities about cheating in general. The same behavioral pattern of students was observed by Barnett \& Dalton (1981). In a research, Payne \& Nantz (1994) found that students see cheating during exams and cheating including other forms of academic purposes differently. In an observation study Roberts \& Rabinowitz (1992) found that the overall students perceptions chiefly depends upon the interplay of multiple factors such as needs, wants, situational provocations, alluring opportunities, and intentional approach. In a study Sutton and Huba (1995) found out that there was a wide gap in the perception of cheating between North American and African-American students. It is observed that students do not see cheating as a major problem among their peers (Daniel et al., 1991). One more fact might also support the conception that when compared the act of plagiarism between academic staff and students, it was surprising to note that students have a very different attitude towards cheating and plagiarism (Stern \& Havlicek, 1986; Roth \& McCabe, 1995; Anderson \& Obershain, 1994). In a study Evans \& Craig (1990) observed that students form an untold kind of agreement to conceal the act of cheating either by themselves or by others which has proved to be a very serious problem. Altogether, an effective step is required to be taken to curb down such practices. A study by Lim and See (2001) which was done at Singapore might stand as an evidential support to prove the same notion. Students assumed that cheating for other academic purposes is not of severe or serious offence. A study by Lim and See (2001) which was done at Singapore might stand as an evidential support to prove the same notion. One more fact might also support the conception that when compared the act of plagiarism between academic staff and students, it was surprising to note that students have a very different attitude towards cheating and plagiarism. Ashworth et al. (1997) strongly recommended that the practice of plagiarism has conceptually less value for students and is a high and sensitive affair for the academic staff members.

\section{Environmental Influences}

In a study, Payne and Nantz (1994) affirmed that the social construction plays a strong and a vital role in nurturing the habit of plagiarism in students. They observed that the academic behavior of students is all an affair of his/her 
social set up. Students follow into the practice of plagiarism in absence of legitimated upbringing environment. They pointed out that the practice of framing and un-plagiaristic attitude might be an outcome of social inputs which may comfortably reconcile their uncontrollable affinity towards views, attitudes and practices relating to cheating between the students of two different social landscapes.

\section{Ways Students Adopt}

Somewhere the concept of plagiarism is related with putting in your efforts to collect the material from different sources at further collating them and incorporating due necessary changes to bring out the desired shape of the content. Following are the different methods through which students generally conduct the practice of plagiarism. Plagiarism is assumed to be stating your name for the works of others. In a study, Bugeja (2000) found that whenever students are given assignments they refer books, newspapers and through other approachable resources and present after making formatting changes as their own. Such habits are flared up by the new technologies.

\section{Factors behind Students' Plagiarism}

Hamilton (2003) observed that the commonest factor behind the major reasons behind students plagiarism is their carelessness. This reason has been obviously supportive and understanding students habit of plagiarism because most of the time students do their assignments at the eleventh hour which naturally compels them to adopt to such prohibited means. Brandt (2002) studied out that most of the time students themselves are ignorant of the right way of citation. They copy certain content through websites or books but they do not know how to visibly display the sources of the content, which ultimately results the act of plagiarism. While according to Brandt (2002), "Plagiarism is theft and lying-using information and passing it off as your own."

Students believe that what they write in assignment might stand incompetent and may draw poor marks by the evaluators. The right way and method of completion of assignment absorbs more time as compared to selecting to latest electronic devices like internet where the contents of almost all the topics are available in abundance. The attitude of plagiarism is further flared up by believing that students do take for granted that teachers are busy people and it is difficult for them to spare time to check the assignments thoroughly.

In order to develop the thorough understanding of students plagiarism or the major reasons associated with it is fruitful to peruse the research of Steven and Stevens (1987), Davis et al. (1992), Love and Simmons (1998) and Straw (2002). Genuine lack of understanding, lack of time, lack of confidence \& poor time management tempts towards foul opportunities.

\section{Information Tech Role}

Internet has really triggered of communication exchange up to a great extent. Such digital development offers an easy access globally. This access has posed great challenges to academia to protect the practice of plagiarism. Further digital sources have made access easy towards copying the contents from e-books and e-journals (Ashworth et al., 1997). Lathrop \& Foss (2000) observed that excessive availability of materials of various topics have undoubtedly allured students' folks. The search engines like google.com on internet is also a very potent medium of supply of such materials to student to plagiarize. Internet has always been a source and motivation of unparalleled temptation providing almost all opportunities of cheating leading to 'cyber cheating' (Stebelman, 1998) or 'cyber plagiarism' (Anderson, 1999), 'mouse click plagiarism' (Auer \& Krupar, 2001) or 'academic cyber-sloth (Carnie, 2001).

\section{Conclusion}

The study indicates that plagiarism has become a way to be followed by students. With the use of new gadgets plagiarism is growing epidemic in approach and access. Plagiarism is a tough challenge for institutions and academicians because its illegally support to students to cheat and get rewarded with good marks. Plagiarism overshadows the actual talent and discourages original approach. It decreases the enthusiasm and motivation of students for putting their best efforts to create the thought and idea of originality with fresh approach. Plagiarism is not limited to one specific region rather it encompasses almost all the nations across the globe. New technology is helping true researchers, students, academicians to make study material available faster and accurate. However, it is also intolerable that the students are making illegal uses of such potential sources of information.

\section{References}

Alschuler AS and Blimling GS (1995) Curbing epidemic cheating through systemic change, College Teaching 43(4): 123-126.

Anderson GL (1999) Cyberplagiarism. College \& Research Libraries News 60(5): 371-375.

Anderson RE and Obenshain SS (1994) Cheating by students: findings, reflections and remedies. Academic Medicine 69: $323-332$.

Ashworth P, Bannister P and Thorne P (1997) Guilty in whose eyes? University students' perceptions of cheating and plagiarism in academic work and assessment, Studies in Higher Edu- cation 22(2): 187-203. 
Auer NJ and Kruper EM (2001) Mouse click plagiarism: the role of technology in plagiarism and the librarian's role in combating it. Library Trends 49(3): 415-433.

Barnett DC and Dalton JC (1981) Why college students cheat. Journal of College Student Personnel 22: 545-551.

Barnhart RK (1988) Chambers Dictionary of Etymology, Edinburgh, Chambers.

Baty P (2002) Plagiarism puts Monash VC out of job. Times Higher Education Supplement 19: 1.

Brandt DS (2002) Copyright's (Not So) Little Cousin, Plagiarism. Computers in Libraries 22(5): 39.

Bugeja M (2000) Bust a plagiarist in 30 minutes or less. Quill 88(3): 44.

Carnie A (2001) How to handle cyber-sloth in academe? Chronicle of Higher Education 47(17): B14.

Daniel LG, Blount KD and Ferrell CM (1991) Academic misconduct among teacher education students: A descriptive-correlational study. Research in Higher Education 32(6): 703-724.

Davis SF, Grover CA, Becker AH and McGregor LN (1992) Academic dishonesty: prevalence, determinants, techniques and punishments. Teaching of Psychology 19(1): $16-20$.

Evans ED and Craig D (1990) Teacher and student perceptions of academic cheating in middle and senior high schools. Journal of Educational Research 84(1): 44-52.

Fialkoff F (1993) There's no excuse for plagiarism. Library Journal 118(17): 56

Hamilton D (2003) Plagiarism. Searcher 11(4): 26

Hanks P (1979) Collins Dictionary of the English Language, Glasgow, William Collins.

Lathrop A and Foss K (2000) Student Cheating and Plagiarism in the Internet Era: a wake-up call (Englewood, CO, Libraries Unlimited).

Lim VKG and See SKB (2001) Attitudes towards, and intentions to report, academic cheating among students in Singapore. Ethics and Behaviour 11(3): 261-275.

Love PG and Simmons J (1998) Factors influencing cheating and plagiarism among graduate students in a college of education. College Student Journal 32: 539-51.

Macilwain C (1998) Congressman launches plagiarism inquiry Nature 392: 113

Marshall S and Garry M (2005) How well do students really understand plagiarism. In: Proceedings of the 22nd annual conference of the Australasian Society for
Computers in Learning in Tertiary Education (ASCILITE) pp. 457-467.

Morgan B and Thomson A (1997) Keele to probe standard of PhDs, Times Higher Education Supplement, 7 November, p. 1.

Paldy LG (1996) The problem that won't go away: addressing the causes of cheating. Journal of College Science Teaching 26 (1): 4-6.

Payne SL and Nantz KS (1994) Social accounts and metaphors about cheating. College Teaching, 42(3): 90-96.

Roberts D and Rabinowitz W (1992) An investigation of student perceptions of cheating in academic situations. Review of Higher Education 15(2): 179-190.

Roig M (2001) Plagiarism and paraphrasing criteria of college and university professors. Ethics and Behaviour 11: 307-324.

Roth NL and Mccabe DL (1995) Communication strategies for addressing academic dishonesty. Journal of College Student Development 36: 531-541.

Sims RL (1995) The severity of academic dishonesty: a comparison of faculty and student views, Psychology in the Schools 32(3): 233-238.

Smith I (1995) Tribunal to reassess plagiarism allegations, Times Higher Education Supplement, 24 February, p. 5.

Stebelman S (1998) Cybercheating: dishonesty goes digital. American Libraries 29(8): 48-51.

Stern EB and Havlicek L (1986) Academic misconduct: results of faculty and undergraduate surveys. Journal of Allied Health 15(2): 129-142.

Stevens GE and Stevens FW (1987) Ethical inclinations of tomorrow's managers revisited. Journal of Education for Business 63(1): 24-29.

Stone R (1996) Alabama challenges fraud award. Science 272: 473.

Straw D (2002) The plagiarism of generation 'why not? Community College Week 14(24): 4-7.

Sutton EM and Huba ME (1995) Undergraduate student perceptions of academic dishonesty as a function of ethnicity and religious participation, NASPA Journal 33(1): 19-34.

Wojtas O (1999) Accused students claim they 'cooperated' not collaborated. Times Higher Education Supplement 27: 36 .

Wong, M. (2004). New Software Detects Plagiarized Passages. Business CustomWire. 